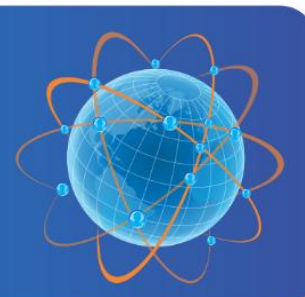

\title{
Sosiologi Kontemporer : Filsafat Dan Orientasi Perubahan
}

Authors : M. Fadhil Nurdin

Published by : Departemen of Sociology, Faculty of Social and Political Science, Universitas Padjadjaran

Accepted : December 2017; Approved : December 2017

Sosiogobal: Jumal Pemikiran dan Penelitian Sosiologi is the Department of Sociology, Faculty of Social and Political Science, Universitas Padjadjaran flagship journal. The Sosioglobal journal founded in 2016 with the mission to publish original works of interest to the discipline of sociology in general, sociological thinking, new theoretical developments, results of research that enhance understanding of fundamental social processes, and methodological innovations. We are welcome a research article, working paper, theoretical/conceptual and methodological review to submit to our journal. In addition, we are accept relevant book review that currently publish and enrich sociological perspectives. Please submit article to http://jurnal.unpad.ac.id/sosioglobal

To cite this article :

Nurdin, M. Fadhil. 2017. Sosiologi Kontemporer : Filsafat dan Orientasi Perubahan. Sosioglobal : Jurnal Pemikiran dan Penelitian Sosiologi 2(1):1-9. 


\title{
SOSIOLOGI KONTEMPORER : FILSAFAT DAN ORIENTASI PERUBAHAN
}

\author{
M. Fadhil Nurdin \\ Prodi Sosiologi, Fakultas Ilmu Sosial dan Ilmu Politik, Universitas Padjadjaran \\ m.fadhil.nurdin@unpad.ac.id
}

\section{PENDAHULUAN}

Makalah ini menyoroti sosiologi yang telah berkembang ke banyak negara di dunia. Sosiologi sebagai disiplin ilmu sosial terus berkembang seiring dengan perkembangan dan perubahan dalam sejarahnya yang panjang, sekitar 600 tahun. Isu sosiologi, tidak terlepas dari pelbagai masalah terkait pemikiran dan teori sosiologi semasa, terutama aplikasi pembangunan untuk kesejahteraan manusia. Karena itu, pemikiran dan teorisasi sosiologi dilakukan dengan mengkaji fakta sosial yang terus mengalami perubahan yang bersumber dari filsafat pemikiran sosial guna membangun teori-teori maupun model-model aplikasi sosiologi.

Sosiologi kontemporer sebagai bagian dalam tahapan perkembangan sosiologi, berazaskan pemikiran empiris obyektif pertengahan abad ke 20, ditandai oleh orientasi subyektifnya. Orientasi pemikiran sosiologis berkembang terus, sebagai bagian reaksi para intelektual terhadap scientific empiricism, terutama sosiologi modern, posmodern dan terkini. Namun, isu penting dalam perkembangan sejarah sosiologi kontemporer ini, Profesor Syed Farid Alatas, menyatakan bahwa studi sosiologi pada awal perkembangannya fokus pada Ibnu Khaldun (1332-1406); pemikir sosial bukan-Barat (abad ke 14) yang dikenal sebagai tokoh pemikir sosial dan teori sosial, disebut dalam sejarah kontemporer.

Bagaimanapun kecenderungan sosiologi di dunia terus berkembang dan mengalami perubahan dalam sejarah panjang, eksistensi dan identitas disiplin ilmu sosiologi mendapat banyak kritik serta mengalami ujian dan tantangan. Dinamika, orientasi dan tantangan yang terjadi, secara filosofis wujud pada realisme sebagai azas sosiologi; dan konstruksionisme sebagai pemikiran pengembangan terhadap "bangun" sosiologi masa kini dan masa hadapan. Orientasi sosiologi terkait dengan globalisasi dan penguatan sosiologi lokalitas, mengarah ke spesialisasi, dan tantangan kini dan masa hadapan 


\section{FILSAFAT SOSIOLOGI}

\section{Realisme: Azas Sosiologi}

Sosiologi merupakan satu disiplin ilmu sosial yang dalam aktivitasnya berazaskan fakta-fakta sosial yang realistik (realism). Studi sosiologi pada awal perkembangannya fokus pada Ibnu Khaldun (1332-1406), dikenal sebagai tokoh pemikir sosial dan teori sosial bukan-Barat (abad ke 14). Karya-karyanya merupakan sejarah bangsa Arab yang berfungsi sebagai pengantar dan informasi tentang dinasti dan peristiwa politik masa lalu yang diungkapkan secara deskriptif empirik (empirisme), diantaranya yang terkenal adalah :

Kita- b al-'Ibar wa Di wa $n$ al-Mubtada ${ }^{-}$'wal-Khabar fi ${ }^{-}$Ayya $m$ al-'Arab wa al-'Ajam wa al-Barbar wa man ' $A$ - s.arahum min Dhawn al-Sult.a $n$ al-Akbar [Book of Examples and the Collection of Origins of the History of the Arabs and Berbers]; Muqaddimah [Prolegomena]; dan Luba- $b$ al-Mub. as.s. al $f_{i}^{-} u s . u^{-} l$ al-di $n$ [The Resumé of the Compendium in the Fundamentals of Religion].

(Syed Farid Alatas, "Tbn Khaldu $n$ and Contemporary Sociology", International Sociology; Review of Books Vol. 21 No. 6 November 2006 Vol 21(6): 782-795).

Fokus sosiologi sebagai disiplin ilmu sosial mulai mengkristal di awal abad ke-19 - dikenal sosok sosiologi klasik seperti Simmel dan Durkheim yang mengukuhkan fondasi dan paradigma sosiologi sebagai disiplin ilmu sosial baru. Dalam perkembangannya, para pemikir sosial dan pendiri disiplin ilmu sosiologi di Eropa meletakkan fondasi sosiologi, seperti Marx, Weber dan Durkheim memiliki dampak pada perkembangan sosiologi dan ilmu sosial lainnya. Konstruksi saintifik awal, banyak teori dan model sosiologi ini merupakan turunan dari pekerjaan mereka yang dikembangkan serta diterapkan dari Barat ke daerah-daerah di luar dunia Eropa, seperti India, Australia, Jepang, Cina, dan kawasan Asia lainnya.

Sosiologi disebut sebagai disiplin ilmu-ilmu sosial, didasarkan pada pemikiran dan pandangan Thomas Kubn yang menyatakan bahwa istilah 'paradigma' relevan dengan ilmu sosial dan terutama sosiologi. Definisi Ritzer tentang paradigma Kuhnian berguna untuk penelitian sosiologi. Paradigma adalah gambaran mendasar dari pokok bahasan dalam sebuah sains. Paradigma ini adalah unit konsensus terluas dalam sebuah sains dan berfungsi untuk membedakan satu komunitas ilmiah (atau sub-komunitas) dari negara lain. Mereka ini menggabungkan, mendefinisikan dan menghubungkan teori, metode dan instrumen yang ada di dalamnya (Ritzer, 1975).

Srinivas dan Panini (1973), menggambarkan penggunaan ilmu-ilmu sosial dari negara-negara Barat fokus pada upaya mencari solusi penyelesaian masalah-masalah sosial ekonomi. Dalam konteks ekonomi, banyak negara yang Pemerintahannya - pada abad ke tujuh belas menggali fungsi untuk merancang kesejahteraan baru. Kondisi ini terkait dengan popularitas sosiologi di 


\section{FADHIL NURDIN}

Amerika Serikat dalam menghadapi pelbagai masalah perubahan yang cepat; seperti urbanisasi, imigrasi, etnisitas, kriminalitas, kenakalan remaja dan pelacuran (Buroway, 2005).

Uraian di atas secara ringkas, menunjukkan bahwa realisme merupakan landasan fundamental bagi sosiologi sebagai sebuah bangun sains sosial. Disiplin ilmu sosiologi juga digambarkan dalam sejarah panjang, berazas filsafat, teori, metodologi dan aplikasinya untuk pembangunan.

\section{Konstruksionime: Penguatan Sosiologi Kontemporer}

Konstruksi sosiologi bermula di Barat, berasas filsafat dan pemikiran sosial menuju sosiologi kontemporer dikenal tokoh-tokohnya antara lain: Weber, Talcott Parsons, Dabrendorf, Immanuel Wallerstein, Anthony Giddens, Herbert Blumer, Erving Goffman, Pierre Bourdieu, Marvin Harris, Robert Merton, Craig Calboun, Gerhard Lenski, Michel Foucault, and Jurgen Habermas sebagai pemikir teoritisi sosial, metodologi dan pengembang sosiologi kontemporer. Kesemua tokoh sosiologi Barat ini, menunjukkan saling menguatkan eksistensi, kewujudan dan identitas sosiologi di mata dunia.

Pengembangan sosiologi di dunia Barat, tetap berazaskan pemikiran sosial dan teori-teori sosial empirisme dengan secara berkelanjutan memberi perhatian terhadap sumbangan para pemikir sosial non-Barat yang se-zaman dengan pendiri disiplin Sosiologi Eropa. Dalam kondisi ini, para Sosiolog Barat semakin lebih sadar akan perannya terutama dalam merespon pemikiran non-barat dalam perkembangan untuk mengokohkan sosiologi barat sebagai sebuah disiplin ilmu sosial yang memiliki fondasi saintifik.

Variasi dan pelbagai bentuk kritik juga terus berkembang; karena kenyataannya, meski lamban, tapi cenderung bisa bersaing, disamping bersamaan berdampingan dengan disiplin bukan ilmu sosial. Sentuhan dan irisan dengan pelbagai bidang disiplin; baik filsafat, teologi, dan ilmu-ilmu pengetahuan yang luas lainnya bukan melemahkan, namun lebih menjadi faktor-faktor penguatan bagi sosiologi, terutama sumbangan dari bidang sains seperti matematika, statistika, fisika, geografi dan ilmu komputer. Keutamaan sumbangan pelbagai bidang ilmu pengetahuan dan teknologi ini memiliki makna ontologis baru, sekaligus untuk melahirkan konstruksi epistimologi dan aksiologi dalam disiplin sosiologi terkini.

Bagaimanapun, dalam pandangan konstruksionisme terkini, 'paradigma' Kuhnian yang berazaskan sumbangan dari sains atau ilmu pengetahuan alam masih menjadi alat analisis yang berharga. Kekuatan saintifik dalam sain sosial, antara lain misalnya untuk melihat dampak perubahan kebijakan ekonomi terhadap konsep sosiologis, gagasan, makna, pemikiran ideologis dalam sosiologi kontemporer.

3 | SDSIOGLLBAL : Jurnal Pemikiran dan Penelitian Sasiologi, Vol. 2, No. I, Desember 2017 


\section{ORIENTASI SOSIOLOGI KONTEMPORER}

\section{Pengembangan Teorisasi}

Teorisasi sosiologi ditunjukkan, azas utamanya adalah pemikiran realistik sesuai fakta dan fenomena kehidupan kemasyakatan (realism). Selain itu, diperlukan juga metodologi sebagai kaedah-kaedah saintifik yang terus juga dikembangkan guna lebih memantapkan sosiologi baru di masa depan. Dengan adanya pengembangan model-model kaedah baru sosiologi, kolaborasi saintifik semakin menarik dikembangkan juga "konstruktivism” untuk membangun, baik teori, metode, model-model pendekatan serta aplikasi sosiologi.

Dalam teorisasi sosiologi, Profesor Syed Farid Alatas (NUS, Singapore) menyebut bahwa Ibnu Khaldun adalah pemikir sosial dan ilmuan sosiologi; beliau merupakan tokoh awal sosiologi dalam sejarah kontemporer. Talcott Parsons (1902-1979) penyumbang teori structural functionalism yang diakui sebagai pengembangan grand theory bagi ilmu sosial, termasuk disiplin sosiologi. Jean Baudrillard, seorang teoritisi sosial era kapitalisme global yang dikenal teorinya mengenai "masyarakat postmodern" menyatakan bahwa media, simulasi, dan cyberblitz, telah mengkonsitusi bidang pengalaman baru, tahapan sejarah dan tipe masyarakat yang baru. Disebut dalam tesisnya sebagai byper-reality. Fondasi filsafatnya adalah kritisisme terhadap pemikiran ilmiah tradisional yang menurutnya telah mengganti realitas dengan ilusi tentang kebenaran. Baudrillard dalam pemikirannya menyatakan, situasi masyarakat kontemporer dibentuk oleh kenyataan bahwa manusia sekarang dikelilingi oleh faktor konsumsi. Kritik lainnya, juga menyatakan bahwa Marx dalam teori kapitalismenya, telah menciptakan sebuah citra teori produksinya pada masyarakat kapitalis. Marx dianggap menerima konsep-konsep dasar dan prinsip-prinsip pendukung dan teoresi kapitalisme, yang dilihatnya tidak melakukan perubahan yang mendasar pada bagian ide- idenya.

Gambaran konstruksionisme, menunjukkan bahwa kekuatan teorisasi sosiologi memiliki karakter, tidak hanya berazaskan pada penelitian empiris, karena ada teori yang dikembangkan. Namun lebih banyak terdapat pada berbagai sumber pemikiran filosofis dan pilihan praktis untuk "nilai-pakai" atau penerapannya demi kepentingan pembangunan manusia. Dalam konteks ini, terdapat tantangan untuk sosiologi antara lain, menciptakan arah keseimbangan bagi praktik pembangunan dan menyelesaikan permasalahan ketidaksetaraan pemikiran teoritis, metodologi, dan aplikasi sosiologi.

\section{Globalisasi dan Penguatan Sosiologi Lokalitas}

Globasasi adalah sistem untuk menduniakan informasi ke pasar dunia bebas. Globalisasi menunjukkan adanya keterbatasan dan ketidakmampuan menduniakan "idea-idea" besar 


\section{FADHIL NURDIN}

produk manusia, termasuk keilmuan sosiologi. Bagaimanapun, karena globalisasi terbatas, maka diperlukan kreativitas dengan sistem keterbukaannnya untuk mengembangkan dan mempercepat globalisasi Sosiologi. Betapa pentingnya kepelbagaian bentuk kekuatan informasi dan kreativitas dalam upaya penyebaran ilmu sosiologi. Kreativitas dalam konteks ini dapat dikatakan sebagai landasan pendekatan dan kekuatan baru untuk mempercepat menduniakan sosiologi.

Dalam globalisasi sosiologi, sangat dikuatkan oleh sistem ajar "taken for granted from the West" akibat lemahnya "critical-views from the East". Gambaran kondisi ini dapat dilihat juga pada tulisan berikut:

"...in the cases of many developing countries, globalization weakens the role of the state and often become a trigger for social disintegration and the emergence of "local" social problems, particularly poverty (Muhamad Fadhil Nurdin, Sociology and Welfare Development, 2015).

Sosiologi Lokalitas, istilah lain disebut nativisme telah dibincangkan oleh Profesor Syed Farid Alatas, dalam buku Diskursus Alternatif Dalam Ilmu-Imu Sosial, Tanggapan Terhadap Eurosentrisme (2010). Menyimak kandungan buku ini, disertai buku-buku ilmu sosial lainnya terkait, penting artinya bagi pemahaman baru; pemikiran kritis untuk sosiologi, bak 'air mengalir' dan 'pantun bersaut' - dengan berlandaskan pada pemikiran, debat dan makna buku Syed Farid Alatas. Pandangan tentang nativisme tidak sekedar kritik terhadap ilmu-ilmu sosial yang tumbuh dan berkembang di Barat; dan mungkin dianggap perlu lahir, tumbuh dan berkembangnya sosiologi lokalitas.

Penguatan sosiologi lokalitas menunjukkan bahwa di Asia, gagasan tentang pembalikan Orientalisme (Barat) atau nativisme (pengukuhan-otonomi), diantaranya telah dikembangkan oleh filsuf Suriah, Sadiq Jalal al'Azm (1984); filsafat Hobbes tentang manusia (insan) berbunyi: "setiap manusia adalah srigala bagi manusia lain". Sementara sebaliknya, filsafat Islam yang tersirat dalam kata 'insan' mengajarkan bahwa "setiap manusia adalah saudara yang lain”. Contoh, misalnya di Jepang, ilmu-ilmu sosial dan juga Sosiologi telah menunjukkan wujudnya 'otonomisasi-sosiologi', semakin berkembang dengan mengokohkan teori sosiologi Jepang. Walau bagaimanapun, situasi dan proses ini juga telah terjadi debat dan serangan hebat terhadap sosiologi, yang pernah terjadi pada tahun 1980an (Syed Farid Alatas, 2010).

Berdasarkan data dan pengalaman juga menunjukkan, kawasan Cina, Jepang dan Korea - pada konferensi International Sosiology and Social Policy (2014) di Hongkong terdapat kecenderungan tumbuh dan berkembangnya sosiologi lokalitas; mazhab baru berdasarkan kawasan - seperti Cina dan Jepang, Negara-negara di Timur Tengah dan Nusantara Indonesia dan Malaysia.

5 SUSIOGLLBAL: Jurnal Pemikiran dan Penelitian Sasiologi, Vol. 2, №. I, Desember 2017 
Azas penting sosiologi lokalitas di kawasan ini, dibangun dengan pijakan filsalat confusionism, bermuara pada kebijakan sosial negara-negara tempatan, seperti Cina, Hongkong, Taiwan, Korea dan Jepang. Dengan demikian, otonomi Sosiologi Lokalitas, terutama di Indonesia dimungkinkan lahir, tumbuh dan berkembang.

Wujudnya eksistensi dan identitas Sosiologi Lokalitas, dimungkinkan dapat terjadi (di) Indonesia, didasarkan pada beberapa pertimbangan, antara lain:

> Sosiologi Dunia, memiliki makna dan sifat relativitas (kecenderungan berdasarkan pandangan Parson terhadap karya Max Weber; utamanya terkait resistensi budaya).

> Globalisasi sosiologi gagal merasuk ke wilayah-wilayah selain Barat. Sejarah dan ketaksamaan budaya merupakan landasan pikiran azasi, bagi wujudnya peluang baru untuk menafsir ulang makna sosiologi yang sekaligus menolak, prinsip dan nilai-nilai universalisme yang seharusnya wujud dalam disiplin ilmu, termasuk ilmu-ilmu sosial dan khususnya sosiologi.

> Para ilmuan non-Barat (selain Jerman \& Prancis) belum mengkaji, menafsir ulang dan mengolah kembali; filsafat dan teori-teori Barat, Marx, Weber, Durkheim atau Foucault dengan menggunakan latar belakang sejarah dan budaya, seperti Indonesia misalnya.

Wujud kecenderungan baru disiplin ilmu-ilmu sosial, termasuk juga sosiologi. Misalnya, di Jepang dengan adanya otonomisasi sosiologi, diartikan sebagai penguatan sosiologi lokalitas.

\section{Penguatan Antar Disiplin dan Arah ke Spesialisasi}

Dalam beberapa tahun kebelakangan, penguatan sosiologi telah dilakukan dengan mengembangkan studi antar-dan bidang ilmu sosial lainnya dengan disiplin sosiologi. Dilengkapi pula studi tentang metode-metode baru; utamanya metode analisis kwantitatif, analisis kualitatif dan metode campuran (mix methods) dengan menggunakan general analytical tools, mengsintesakan pendekatan-pendekatan teoritis, memfasilitasi dialog dan diskusi para teoritisi ilmu-ilmu sosial yang berbeda, memperluas pembicaraan tentang isu-isu konseptual, batasan politik, menganalisis pemikiran teori dan metodologi terkini, mendiagnosis kondisi sosial kontemporer serta tantangan memantapkan teori-teori sosiologi.

Dalam studi sosiologi dengan bidang Teologi telah dilakukan Kieranc Flanagan (2009) dalam Sociology in Theology: Reflexivity and Belief ini tidak memetakan secara sistematis; Dia juga tidak peduli dengan metodologi, atau kompleksitas kerja antar-disiplin. Bagaimanapun, Sosiologi dalam Teologi merupakan usaha penulis untuk menggali dan menempa keterkaitan kedua SGSIOGLBBAL : Jurnal Pemikiran dan Penelitian Sosiologi, Vol. Z, No.I, Desember 2017 | 6 


\section{FADHIL NURDIN}

bidang ilmu tersebut. Poin penting perdebatan karya Flanagan adalah status epistemologis sosiologi, dan apa yang diharapkan darinya ketika pandangan dunia teologis - secara terus terang didukung. Disisi lain, sosiologi dikritik karena ketidak mampuannya untuk memahami dilema sosial yang berulang. Keterkaitan dan hubungan antar sosiologi dengan Teologi ini menunjukkan, para Teolog membutuhkan apresiasi dari apa yang sosiologi sumbangkan, dan pemahaman para Sosiolog yang realistik terhadap aktivitas Teologi (reflexive sociology).

Banyak studi sosiologi kontemporer lain yang dilakukan, Andrew Abbott, John Goldthorpe, and Bruno Latour asal Amerika dan Eropa berpendapat bahwa perubahan deskriptif yang tampak pada kapitalisme kontemporer menantang penekanan sosiologi ortodoks tentang pentingnya kausalitas dan pengembangan metode deskriptif. Mereka mengulas evolusi sosiologi deskriptif yang mengemukakan pendekatan mereka yang berbeda terhadap peran ' sosiologi deskriptif', sehingga perlu ditempatkan dalam orientasi sosiologi yang lebih luas, terutama dari perspektif historisnya, humaniora dan ilmu pengetahuan alam. Selanjutnya, bagaimana reorientasi ini melibatkan peran baru untuk metode visual yang secara tradisional telah dicela dalam sosiologi ortodoks yang mereka kaji, sarannya; bagaimana sosiologi lebih mengarahkan dirinya pada putaran deskriptif ?

Tiago Correia (2017) dari ISCTE - Instituto Universitário de Lisboa, Portugal; menulis artikel; Sociology of professions, menggambarkan bagaimana hubungan antar institusi dan dinamika perilaku beroperasi di antara dokter di organisasi rumah sakit. Didasarkan penelitian kualitatif mendalam yang dilakukan di sebuah organisasi rumah sakit, dengan fokus pada dokter dari dua lingkungan, perbedaan dalam tindakan dan diskursus mereka menantang koherensi yang terkait dengan nilai profesional dan organisasi yang ditemukan di perdebatan dalam sosiologi profesi. Artikel ini menghubungkan mereka dengan cara profesional dan refleksif memanfaatkan peran mereka di tempat kerja. Karena itu, tidak hanya membahas fakta bahwa dokter medis berazaskan pemikiran yang diliputi oleh keragaman pengaruh - etika, manajemen, budaya organisasi dan subkultur; tetapi juga bahwa mereka membuat pertimbangan refleksif atas dasar kepentingan yang terkait dengan konteks tertentu. Analisis dibangun melalui diskusi di neo-institusionalisme selaras dengan realisme kritis, untuk memperbaiki argumen teoritis tentang refleksivitas sambil menyediakan alat untuk penelitian empiris di masa depan dalam sosiologi profesi.

7 SDSIOGLLBAL : Jurnal Pemikiran dan Penelitian Sasiologi, Vol. 2, No. I, Desember 2017 


\section{SIMPULAN}

Sosiologi berasas filsafat pemikiran sosial realisme dan konstruksionime sebagai pijakan azasi sosiologi, dan kajian-kajian sain sosial, mampu membangun sosiologi kontemporer. Pengembangan teorisasi sosiologi terus berkembang sesuai fakta dan fenomena kehidupan kemasyakatan (realism). Selain itu, diperkuat dengan metodologi sebagai kaedah-kaedah saintifik, serta aplikasinya, dikembangkan guna lebih memantapkan sosiologi baru di masa depan. Dengan adanya perkembangan globalisasi dan penguatan sosiologi lokalitas, pengembangan model-model kaedah baru sosiologi, kolaborasi saintifik semakin menarik untuk membangun teori, metode, model-model pendekatan serta aplikasi sosiologi. Akhirnya dapat dikembangkan inovasi dengan kekuatan-kekuatan baru (new-strenghthening); berlandaskan kreativitas dengan keterbukaan, terutama untuk pembangunan dan penyelesaian masalahmasalah sosial.

Orientasi sosiologi kontemporer, wujud dalam penguatan teorisasi seperti "grand theory" sosiologi Talcott Parsons pada teori structural functionalism. Penguatan teorisasi sosiologi postmodern Jean Baudrillard, fokus pada era kapitalisme global. Globasasi adalah sistem untuk menduniakan informasi ke pasar dunia bebas. Globalisasi sosiologi, sangat dikuatkan oleh sistem ajar "taken for granted from the West" akibat lemahnya "critical-views from the East".

Skenario dan agenda untuk perubahan perlu diikuti transformasi demokratisasi sosiologi; sebagai proses penentuan dan pemberian kebebesan berfikir sosiologis. Dimulai dari upaya; membangunan kreativitas dalam sistem pendidikan sosiologi di perguruan tinggi (S1-S3 \& Guru besar) yang kondusif bagi para pihak terkait mendalami serta mengembangkan sosiologi murni maupun terapan.

\section{DAFTAR PUSTAKA}

Burawoy, M. 2005. 2004 Presidential Address for Public Sociology. American Sociological Review,70, 4-28. doi:10.1177/000312240507000 102

Mathew, Georgeorat. "New Economic Policy, Social Development and Sociology”. Sociological Bulletin, Vol.44 No.1 (March 1995).

Chua, Hoi-wai, Antony K.W. Wong and Daniel T.L. Shek, "Social Development in Hongkong: Development Issues Identified by Social Development Index (SDI)", Social Indicators Research, Vol. 95, No.3. Quality of Life of Chinese People in a Changing World (February, 2010).

Savage, Mike.Contemporary Sociology and the Challenge of Descriptive Assemblage. European Journal of Social Theory 12(1): 155-174.

Nurdin, M. Fadhil (eds). 2015. Sociology and Welfare and Development.Yogyakarta : Penerbit Samudra Biru 
Srinivas M.N. dan M.N. Panini, "The Development of Sociology and Social Anthropology in India" (Sociological Bulletin, Vol.22, No.2 - September 1973).

Kelly, Stephanie, Tony Stanley, Where Science Meets Art: Sociology and Social Work, in Sociology Mind 2012. Vol.2, No.4, 335-341 Published Online October 2012 in SciRes (http:// www.SciRP.org/journal/sm) DOI:10.4236/sm.2012.24044).

Alatas, Syed Farid. 2010.Diskursus Alternatif dalam Ilmu Sosial ASIA: Tanggapan terbadap Eurosentrisme. Jakarta : Mizan Publika

Correia, Tiago. "Doctors' reflexivity in hospital organisations: The nexus between institutional and behavioural dynamics in the sociology of professions", jurnal Current Sociology, 2017, Vol. 65 (7) 1050-1069.

Weber, Max. 1922. The Sociology of Religion. Boston : Beacon Press

9 SDSIOGLLBAL: Jurnal Pemikiran dan Penelitian Sasiologi, Vol. 2, №. I, Desember 2017 